\title{
CHILDREN VS ELDERLY IN ORTHOPEDIC SURGERY SITE OF INFECTION. ARE THERE DIFFERENCE? EXPERIENCE OF A HIGH VOLUME PLASTIC SURGEON CONSULTANT
}

\author{
Raffaele Franzese', Michele Conte ${ }^{1}$, Nicola Gagliardo², Gorizio Pieretti ${ }^{3}$
}

(C) 2019 by Acta Medica Saliniana ISSN 0350-364X

DOI: $10.5457 / 504$

Raffaele Franzese1, Michele Conte1, Nicola Gagliardo2, Gorizio Pieretti3

\section{Afiliations:}

1Section of Orthopedic and Traumatology, Multidisciplinary Department of Medico-Surgical and Dentistry Specialties, University "Campana Luigi Vanvitelli", Napoli, Italy, 2Unit of Orthopedic and Traumatology, "San Giuliano" Hospital, Giugliano(Napoli), Italy, 3 Section of Plastic and Reconstruction Surgery, Multidisciplinary Department of Medico-Surgical and Dentistry Specialties, University "Campana Luigi Vanvitelli”, Napoli, Italy

Received:

03.06.2019.

\section{Accepted:}

01.11.2019.

\section{Corresponding author:}

Raffaele Franzese, MD

Section of Orthopedic and

Traumatology, Multidisciplinary

Department of Medico-Surgical and

Dentistry Specialties, University

"Campana Luigi Vanvitelli", Napoli, Italy

E-mail: ortoplastic@outlook.it

Phone: +393403443697

Funding: none

Competing interests: none

\section{ABSTRACT}

Introduction: Prevention of surgical site infection in surgery and bone trauma has some hallmarks not shared with other surgical disciplines. The surgeon is not always able to open the pathogen and a key to correct therapy. The aim of our work is to verify if there are differences between pathogens, and treatment between the two groups most susceptible to skin infections by means of synthesis such as children and the elderly.

Materials and Methods: From January 2011 to December 2018, we perform 3189 consultancies in various departments of orthopedics and traumatology. From the exclusion criteria we recruited 168 patients with superficial infection of the surgical site after orthopedic surgery. A group represented by children (under 12 years old) and a group of older people over 65 . The evaluation criteria between the two groups were: the infectious bacterial flora; the type of antibiotic, the duration of antibiotic therapy; the type of medications used in the post-operative period, the complications.

Results:The results showed that elderly patients are more likely to be bacterial superinfection due to poor hygiene. Therapy in children is shorter and has minor complications. Proper management of the surgical site showed a rapid resolution of the infection in both groups.

Conclusion: The correct management and hygiene of the surgical site allows its rapid recovery from infection. The plastic surgeon management of the fracture site infection can be a winning weapon in the treatment of this problem both in the child and in the elderly.

Key Words: Child; Granny; Skin; Infection; Orthopedic; Trauma.

\section{INTRODUCTION}

Orthopedic implants have become essential components of modern medicine[1].

The number of orthopedic and trauma performed in the United States each year continues to increase, as does the incidence of septic complications[2]. The changing profile of antibiotic resistant bacteria has made the prevention and the treatment of skin infection increasingly complex [3]. A correct and early diagnosis is essential in order to provide the most appropriate therapy. If a correct and timely microbiological diagnosis of infections is done within 4 weeks, it could be possible to follow a conservative approach on the prosthesis, since microorganisms are not yet organized in biofilms.

A delayed diagnosis ( $>4$ weeks) of early and late infections involves the necessity of devices removal $[2,4,5]$ due to the production of a structurated and mature microbial biofilm. Biofilm is an aggregate of microcolony of microbial cells adherent to a living or nonliving surface embedded in an extracellular polymeric matrix. Biofilm renders bacteria highly tolerant to antibiotics and host defenses [6-8]. Unfortunately, infections of the orthopedic-traumatological surgical site are very common in children [9] and in the elderly [10-20].The aim of our work is to verify if there are differences between pathogens, and treatment between the two groups most susceptible to skin infections by means of synthesis such as children and the elderly.

\section{MATERIALS AND METHODS}

From January 2011 to december 2018, we perform 3189 consultancies in various departments of orthopedics and traumatology.

From the inclusion and exclusion criteria we recruited 168 patients with superficial 
infection of the surgical site after orthopedic surgery Inclusion criteria: patients who sustained a single trauma or orthopedic surgery, patients under 12 years old or over 65 years old.

Exclusion criteria: hematological or oncological patients, presence of acute or chronic infections; age under 13 or over 64 years old, bone metabolism disorders, rheumatological diseases, polytrauma, no previous injury on ipsilateral lower legs.

We divide the 168 patient in two groups(Table 1). The first group of 68 patients was Child(under 12 years old). The second group of 100 patients was Eldery(Over 65 years old.)

All patients were informed in a clear and comprehensive way of the type of treatment and other possible surgical and conservative alternatives. Patients were treated according to the ethical standards of the Helsinki Declaration, and were invited to read, understand, and sign the informed consent form.

The evaluation criteria between the two groups were: the infectious bacterial flora; the type of antibiotic, the duration of antibiotic therapy; the type of medications used in the post-operative period, the complications

\section{STATISTIC ANALYSIS}

Descriptive statistics were used to summarize the characteristics of the study group and subgroups, including means and standard deviations of all continuous variables. The t-test was used to compare continuous outcomes. The Chi-square test or Fisher's exact test (in subgroups smaller than 10 patients) were used to compare categorical variables. The statistical significance was defined as $\mathrm{P}<0.05$. We used Pearson correlation coefficient ( $\mathrm{r}$ ) was used to compare the predictive score of outcomes and quality of life. Mean ages (and their range) of the patients were rounded at the closest year. The predictive score of outcomes and quality of life and their ranges were approximated at the first decimal while at the second decimal was approximated Pearson correlation coefficient (r).

\section{RESULTS}

Statistically significant differences exist between the two populations by age difference in sex distribution to the benefit of the child population (Table 1 ).

Table 1. Description of the populations.

\begin{tabular}{|c|c|c|}
\hline Description of population & Child & Elderly \\
\hline Number of Patients & 68 & 100 \\
\hline $\begin{array}{l}\text { Average age, years } \\
\text { (standard deviation) }\end{array}$ & $9.67( \pm 2.29)$ & $73.56( \pm 7.82)$ \\
\hline Range of age. years & $3-12$ & $65-102$ \\
\hline Gender Ratio (male:female) & 1.27(38:30) & $0.67(40: 60)$ \\
\hline Type of surgery & $\begin{array}{c}\text { Orthopedic: 28(46.67\%) } \\
\text { Trauma: 40(53.33\%) }\end{array}$ & $\begin{array}{c}\text { Orthopedic: 52(52\%) } \\
\text { Trauma: 48(48\%) }\end{array}$ \\
\hline Site of Infection & $\begin{array}{c}\text { Spine: 2(2.94\%) } \\
\text { Shoulder: 4(5.88\%) } \\
\text { Humerus: 4(5.88\%) } \\
\text { Elbow: 5(7.35\%) } \\
\text { Forearm: 55(7.35\%) } \\
\text { Wrist: 2(2.94\%) } \\
\text { Hand: 3(4.41\%) } \\
\text { Pelvis: 1(1.47\%) } \\
\text { Hip: 55 (7.35\%) } \\
\text { Femurus: 6(8.82\%) } \\
\text { Knee: 3(4.41\%) } \\
\text { Leg: 12(17.65\%) } \\
\text { Ankle: 6(8.82\%) } \\
\text { Foot: 6(8.82\%) }\end{array}$ & $\begin{array}{c}\text { Spine: 7(7\%) } \\
\text { Shoulder: 9 (9\%) } \\
\text { Humerus: 5(5\%) } \\
\text { Elbow: 5(5\%) } \\
\text { Forearm: 7(7\%) } \\
\text { Wrist: 5(5\%) } \\
\text { Hand: 5(5\%) } \\
\text { Pelvis: 6(6\%) } \\
\text { Hip: 5(15\%) } \\
\text { Femurus: 8(8\%) } \\
\text { Knee: 15(15\%) } \\
\text { Leg: 4(4\%) } \\
\text { Ankle: 5(5\%) } \\
\text { Foot: 4(4\%) }\end{array}$ \\
\hline
\end{tabular}


Regarding the only hip and knee surgical sites there is a statistically significant difference for the Child group, as less affected.

In the patients of the Child group we found that the infection is monoagent, to the three tampons made on wound or surgical wounds there were never overlaps of bacterial colonies, however we also found multiresistant pathogens (Fig.1).

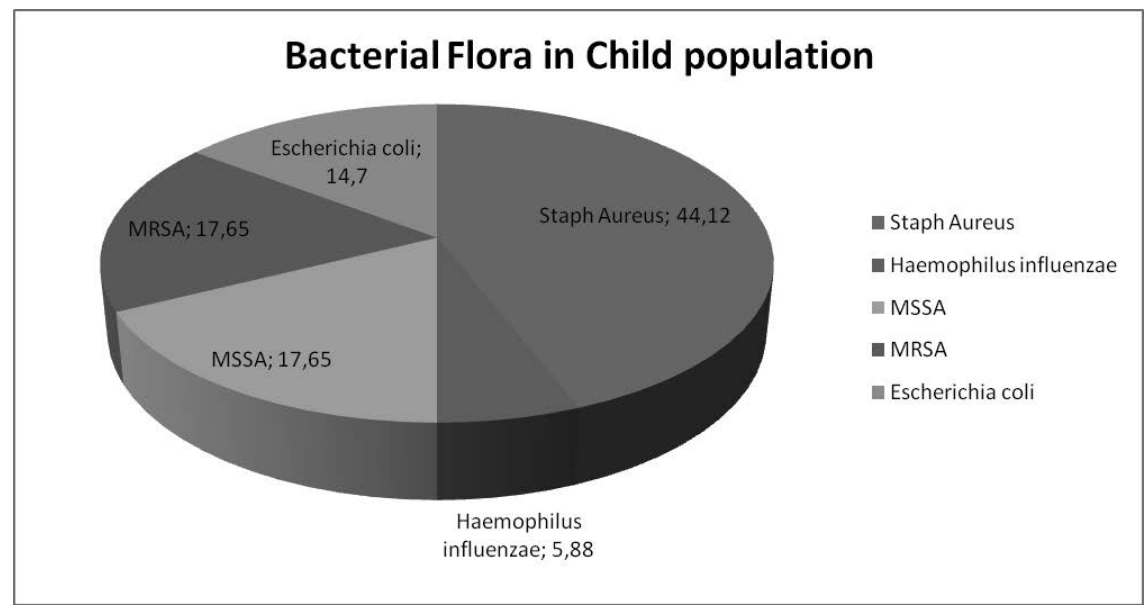

Figure 1: The infection in children has always been monoagent.

In the Elderly group we found 173 patients with surgical site infection with the most infectious beating being $\mathrm{E}$. Coli in 30 cases. In 5 cases we had 4 contaminants, in 15 cases three contaminants, in 4 cases 2 contaminants(Fig.2).

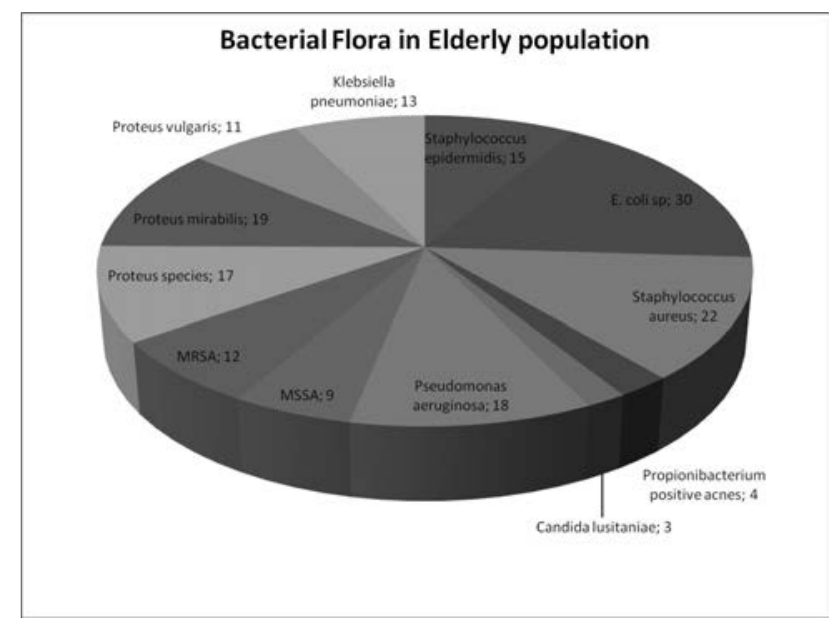

Figure 2: The infection in eldery has a high incidence of infections of 2, 3 or 4 bacteria in the same surgical site.

Pharmacological therapy was always selective in children, instead in the elderly it was in 43 monopharmaceutical cases in the remaining 57 combined.

Furthermore, in Child patients we had 4 delays of healing of the surgical wound. While in the elderly we had in the 23 recovery delays of the surgical erita, 10 treated with vac theraphy, 10 with advanced medications and 7 with surgical wound revision.

We did not have any complications due to treatment for the infected surgical wound in both groups.

\section{DISCUSSION}

The incidence of skin surgical infection in the general population ranges widely, from $0.1 \%$ for minor surgery up to $50 \%$ for tumor related and transplant surgery[21-42].

Signs of wound infection include pus, spreading redness, increased pain or swelling, and fever a break in the skin (a wound) shows signs of infection. They includes: infected cuts, scrapes, sutured wounds, puncture wounds and animal bites; most dirty wounds become infected 24 to 72 hours later[21].Caring for child's wound is important to promote healing, avoid infection and minimise scarring. Different types of wounds require different dressing products and care. Your doctor or nurse will provide specific instructions, organize follow-up and discuss a home dressing management plan[22].To prevent your child's wound from getting infected, hold the area under cool water for a couple of minutes. Avoid using rubbing alcohol, hydrogen peroxide and similar agents to disinfect the wound, as they can lead to irritation and pain. Methicillin-resistant Staphylococcus aureus (MRSA) is staph that can't be killed with common antibiotics, such as penicillin and amoxicillin.

MRSA can be life-threatening if it spreads from the skin to the lungs, the bloodstream, or other organs. MRSA infection can be hard to treat. But other oral or intravenous (IV) antibiotics can successfully treat the infection. The infection can be easier to treat if caught early. When the child has a mild MRSA skin infection, the healthcare provider will likely treat it by opening the infected sore and draining out the fluid (pus)[23]. Most MSSA infections are easily treated with antibiotics or by draining the infection of pus or fluid. Many such infections can be prevented by washing hands well and often, keeping cuts and scrapes clean and covered with a bandage, not sharing personal items (like razors, towels, or uniforms), and making sure to take the full 
amount of any antibiotics as prescribed[24].Skin and soft tissue infections are among the most common infections in children and are nearly always caused by $\mathrm{S}$. aureus or S. pyogenes, which are sensitive to firstline antibacterials. A few localized lesions may be treated with topical antibacterials such as mupirocin or fusidic acid, but multiple and/or extensive lesions require systemic antibacterials. The treatment of choice remains the penicillinase-resistant penicillins such as cloxacillin and flucloxacillin. In adults, current treatment recommendations are cefazolin or ocloxacillin[25]. Il the elderly many factors may influence the probability of developing an surgical skin infection after a surgical intervention. Risk factors for the occurrence of surgical skin infection in the general population have been well described in several reports and include variables related to the surgical procedure (increased duration, blood loss and transfusion, wound class , factors related to the operative environment, use of medical devices, duration of hospitalization before surgery)[26]. The most frequent agents responsible for SSI in the elderly are S. aureus (51.6\%), followed by coagulasenegative staphylococci (8.3\%), and Enterococcus spp. (6.4\%). Other commonly isolated pathogens include Escherichia coli (5.6\%), Pseudomonas aeruginosa (3.0\%), Proteus spp. (2.3\%), and Streptococcus spp. (1.9\%)[27]. Guidelines on antibiotic prophylaxis provide recommendations for selection of the appropriate antimicrobial for each surgical intervention [28]. However, the antibiotic is not always enough to reduce the virulence for bacterial (very often polymicrobial) in infecting the surgical sites very often it is necessary to resort to advanced medications such as vac, silver dressings and etc $[21,29]$. Without a doubt the difference in results between children and the elderly in skin healing is due to a biological-anatomical factor. Indeed the changes in skin quality over one's lifetime can be attributed to internal and external influences to its cellular and molecular structure. For example, it's clear to most people that baby skin is generally smoother and more supple than adult skin. One reason is because baby skin generally contains slightly higher water content. While an infant is estimated to be roughly $75 \%$ water, adults are closer to $65 \%$ water and the elderly are closer to $55 \%$ water. You can think of baby skin like a sponge that has absorbed more water and thus feels softer and more flexible than a drier sponge. Furthermore, the collagen, other connective proteins, and fat content in the skin change as we age, which can explain some of the laxity and loss of volume that naturally occurs over time[30-51].

\section{CONCLUSIONS}

From the data in the literature and from our experience, we can say that the two age groups most affected by children and elderly infections are susceptible to surgical site infections due to poor hygiene. When dealing with these infections, a reasoned therapy must always be done. The plastic surgeon management of the fracture site infection can be a winning weapon in the treatment of this problem both in the child and in the elderly.

\section{REFERENCES}

1. Falzarano G, Piscopo A, Rollo G, Medici A, Grubor P, Bisaccia M, Pipola V, Cioffi R, Nobile F, Meccariello L. Tantalum in type IV and V Paprosky periprosthetic acetabular fractures surgery in Paprosky type IV and $\mathrm{V}$ periprosthetic acetabular fractures surgery. Musculoskelet Surg. 2018; 102(1):87-92. doi: 10.1007/ S12306-017-0503-y.

2. Falzarano G, Piscopo A, Grubor P, Rollo G, Medici A,Pipola V, Bisaccia M, Caraffa A, Barron EM, Nobile F, Cioffi R, Meccariello L. Use of Common Inflammatory Markers in the Long-Term Screening of Total Hip Arthroprosthesis Infections: Our Experience. Advances in Orthopedics Volume 2017 (2017), Article ID 9679470, 7 pages. https://doi. org/10.1155/2017/9679470

3. Bisaccia M, Manni M, Colleluori G, Falzarano G, Medici A, Meccariello L, Rinonapoli G, Schiavone A, Ibáñez Vicente C, Ferraro A, Caraffa A. The Management Of Pin-Care In External Fixation Technique: Povidone-Iodine Versus Sodium Hypochlorite 0,05\% (Amukina-Med ${ }^{\circledR}$ ) Medications. EMBJ 2016, 11 (10):81-87. DOI: 10.3269/19705492.2016.11.10

4. Rollo G, Tartaglia N, Falzarano G, Pichierri P, Stasi A, Medici A, Meccariello L. The challenge of nonunion in subtrochanteric fractures with breakage of intramedullary nail: evaluation of outcomes in surgery revision with angled blade plate and allograft bone strut. Eur J Trauma Emerg Surg. 2017; 43(6):853861. doi: 10.1007/sooo68-016-0755-5.

5. Grubor P, Mitković M, Milan Grubor M, Mitković M, Meccariello L, Falzarano G. Biomechanical Stability of Juvidur and Bone Models on Osteosyntesic Materials. Acta Inform Med. 2016; 24(4): 261-265. doi: 10.5455/aim.2016.24.261-265

6. Grubor P, Falzarano G, Grubor M, Piscopo A, Franzese $\mathrm{R}$, Meccariello L: Treatment of the chronic war tibial osteomyelitis, Gustilo type IIIB and Cierny-Mader IIIB, using various methods. A Retrospective study. EMBJ 2014;9(2):7-18. Available online at: http:// www.embj.org/images/ISSUE_2014/grubor_2.pdf

7. Grubor P, Milicevic S, Grubor M, Meccariello L. Treatment of Bone Defects in War Wounds: Retrospective Study.Med Arh. 2015 Aug; 69(4): 26o264. doi: 10.5455/medarh.2015.69.260-264

8. Rollo G, Falzarano G, Ronga M, Bisaccia M, Grubor P, Erasmo R, Rocca G, Tomé-Bermejo F, GómezGarrido D, Pichierri P, Rinonapoli G, Meccariello L.Challenges in the management of floating knee injuries: Results of treatment and outcomes of 224 consecutive cases in 10 years. Injury. 2019. pii: Soozo1383(19)30113-5. doi: 10.1016/j.injury.2019.03.016.

9. Rollo G, Guida P, Bisaccia M, Pichierri P, Filipponi M, Lanzetti RM, Caraffa A, Stasi A, Russi V, Lupariello $\mathrm{D}$, Meccariello L. TEN versus external fixator in the management of pediatric diaphyseal femoral fractures: evaluation of the outcomes. Eur J Orthop Surg Traumatol. 2018. doi: 10.1007/so0590-018-22013. 
10. Khan MS, Di Giacomo LM, Meccariello L, Bisaccia M, Azzam W, Jatoi A, Rollo G. Ilizarov technique, satisfactory outcome with limited resources. Clin Cases Miner Bone Metab. 2018;15(2):221-226.doi: 10.11138/ccmbm/2018.15.2.221

11. Falzarano G, Pica G, Medici A, Rollo G, Bisaccia M, Cioffi R, Pavone M, Meccariello L. Foot Loading and Gait Analysis Evaluation of Nonarticular Tibial Pilon Fracture: A Comparison of Three Surgical Techniques. J Foot Ankle Surg. 2018 Jun 15. pii: S10672516(18)30097-8. doi: 10.1053/j.jfas.2018.03.025.

12. Schiavone A, Bisaccia M, Inkov I, Rinonapoli G, Manni M, Rollo G, Meccariello L, Vicente CI, Ceccarini P, Ruggiero C, Caraffa A. Tranexamic Acid in Pertrochanteric Femoral Fracture: Is it a Safe Drug or Not? Folia Med (Plovdiv). 2018;6o(1):67-78. doi: 10.1515/folmed-2017-0070.

13. Falzarano G, Piscopo A, Rollo G, Medici A, Grubor P, Bisaccia M, Pipola V, Cioffi R, Nobile F, Meccariello L. Tantalum in type IV and V Paprosky periprosthetic acetabular fractures surgery in Paprosky type IV and $\mathrm{V}$ periprosthetic acetabular fractures surgery. Musculoskelet Surg. 2018; 102(1):87-92. doi: 10.1007/ s12306-017-0503-y.

14. Petruccelli R; Bisaccia M; Rinonapoli G; Rollo G; Meccariello L; Falzarano G; Ceccarini P; OlBisaccia O; Giaracuni M; Caraffa A. Tubular vs Profile Plate in Peroneal or Bimalleolar Fractures: is There a Real Difference in Skin Complication? A Retrospective Study in Three Level I Trauma Center. Med Arh. 2017; 71(4): 265-269. doi: 10.5455/medarh.2017.71.265-269

15. Medici A, Meccariello L, Rollo G, De Nigris G, Mccabe SJ, Grubor P, Falzarano G. Does routine carpal tunnel release during fixation of distal radius fractures improve outcomes? Injury, Int. J. Care Injured 48S3 (2017) S30-S33. DOI: http://dx.doi. org/10.1016/Soo20-1383(17)30654-X

16. Maiettini D, Orgera G, Bisaccia M, Piscitelli L, Laurino F, Meccariello L, Rebonato S, Schiaroli E, Rossi M, Rebonato A. Percutaneous Vertebroplasty Improves Pain Control and Quality of Life in Patients Suffering from Back Pain: A Single Center Experience. Iran J Radiol. In Press:e41746. doi: 10.5812/iranjradiol.41746.

17. Carta S, Fortina M, Riva A, Meccariello L, Cataldi C, Colasanti GB, Ferrata P . Is there a rationale in the use of the bone strut allograft for management and internal fixation in periprosthetic humeral fractures? A CASE REPORT. EMBJ2017; 12(24): 115118. DOI: 10.3269/1970-5492.2017.12.24

18. Meccariello L, Muzii VF, Falzarano G, Medici A, Carta S, Fortina M, Ferrata P.Dynamic corset versus three-point brace in the treatment of osteoporotic compression fractures of the thoracic and lumbar spine: a prospective, comparative study.Aging Clin Exp Res. 2017 Jun;29(3):443-449. doi: 10.1007/s40520016-0602-x.

19. Battistelli S, Fortina M, Carta S, Guerranti R, Nobile F, Ferrata P.Serum C-reactive protein and procalcitonin kinetics in patients undergoing elective total hip arthroplasty. Biomed Res Int. 2014;2014:565080. doi: $10.1155 / 2014 / 565080$.

20. Rollo G, Pellegrino M, Filipponi M, Falzarano G, Medici A, Meccariello L, Bisaccia M, Piscitelli L, Caraffa A. A case of the management of Heterotopic ossification as the result of acetabular fracture in a patient with traumatic brain injury. International
Journal of Surgery Open 1 (2015) 30-34. DOI:10.1016/j. ijso.2016.03.0o1

21. Dissemond J, Böttrich JG, Braunwarth H, Hilt J, Wilken P, Münter KC. Evidence for silver in wound care - meta-analysis of clinical studies from 20002015. J Dtsch Dermatol Ges. 2017; 15(5):524-535. doi: 10.1111/ddg.13233.

22. White-Chu EF, Le T, Cordrey R. Implementing a Chronic Wound Care Workshop for Internal Medicine Residents. Adv Skin Wound Care. 2019;32(2):85-87. doi: 10.1097/o1.ASW.0oo0549609.21974.6f

23. Kalra L, Camacho F, Whitener CJ, Du P, Miller M, Zalonis C, Julian KG. Risk of methicillin-resistant Staphylococcus aureus surgical site infection in patients with nasal MRSA colonization. Am J Infect Control. 2013;41(12):1253-7. doi: 10.1016/j. ajic.2013.05.021.

24. Warner SJ, Uppstrom TJ, Miller AO, O’Brien ST, Salvatore CM, Widmann RF, Perlman SL. Epidemiology of Deep Surgical Site Infections After Pediatric Spinal Fusion Surgery. Spine (Phila Pa 1976). 2017;42(3):E163-E168. doi: 10.1097/ BRS.0000000000001735.

25. Dissemond J, Böttrich JG, Braunwarth H, Hilt J, Wilken P, Münter KC. Evidence for silver in wound care - meta-analysis of clinical studies from 20002015. J Dtsch Dermatol Ges. 2017 May;15(5):524-535. doi: 10.1111/ddg.13233.

26. Cataldo MA, Granata G, Petrosillo N. Antibacterial Prophylaxis for Surgical Site Infection in the Elderly: Practical Application. Drugs Aging. 2017 Jul;34(7):489-498. doi: 10.1007/s40266-017-0471-9.

27. Kaye KS, Anderson DJ, Sloane R, et al. The impact of surgical site infection on older operative patients. J Am Geriatr Soc. 2009;57(1):46-54. doi:10.1111/j.15325415.2008.02053.x.

28. Bratzler DW, Dellinger EP, Olsen KM, Perl TM, Auwaerter PG, Bolon MK, Fish DN, Napolitano LM, Sawyer RG, Slain D, Steinberg JP, Weinstein RA, American Society of Health-System Pharmacists; Infectious Disease Society of America; Surgical Infection Society; Society for Healthcare Epidemiology of America. Clinical practice guidelines for antimicrobial prophylaxis in surgery. Am J Health Syst Pharm. 2013;70(3):195-283. doi:10.2146/ajhp120568.

29. Li PY, Yang D, Liu D, Sun SJ, Zhang LY. Reducing Surgical Site Infection with Negative-Pressure Wound Th erapy After Open Abdominal Surgery: A Prospective Randomized Controlled Study. Scand J Surg. 2017;106(3):189-195. doi: 10.1177/1457496916668681.

30. Heyer K, Augustin M, Protz K, Herberger K, Spehr C, Rustenbach SJ. Effectiveness of advanced versus conventional wound dressings on healing of chronic wounds: systematic review and metaanalysis. Dermatology. 2013;226(2):172-84. doi: 10.1159/ooo348331.

31. Bonura EM, Morales DJO, Fenga D, Rollo G, Meccariello L, Leonetti D, Traina F, Centofanti F, Rosa MA. Conservative Treatment of Spondylodiscitis: Possible Therapeutic Solution in Case of Failure of Standard Therapy. Med Arch. 2019;73(1):39-43. doi: 10.5455/medarh.2019.73.39-43. Rollo G, Falzarano G, Ronga M, Bisaccia M, Grubor P, Erasmo R, Rocca G, Tomé-Bermejo F, Gómez-Garrido D, Pichierri P, Rinonapoli G, Meccariello L. Erratum to "Challenges in the management of floating knee injuries: Results 
of treatment and outcomes of 224 consecutive cases in 10 years" [Injury 50 (2) (2019) 453-461]. Injury. 2019;50(2):R4. doi: 10.1016/j.injury.2019.03.018.

32. Fortina M, Maniscalco P, Carulli C, Meccariello L, Colasanti GB, Carta S. Jockey injuries during the Siena "Palio". A 72-year analysis of the oldest horse race in Italy. Injury. 2019. pii: Soo20-1383(19)30112-3. doi: 10.1016/j.injury.2019.03.015.

33. Fortina M, Maniscalco P, Carulli C, Meccariello L, Colasanti GB, Carta S. Jockey injuries during the Siena "Palio". A 72-year analysis of the oldest horse race in Italy. Injury. $2019 \mathrm{Feb} ; 50(2): 365-368$. doi: 10.1016/j.injury.2018.12.014. Erratum in: Injury. 2019 Feb;50(2):R1.

34. Rollo G, Falzarano G, Ronga M, Bisaccia M, Grubor P, Erasmo R, Rocca G, Tomé-Bermejo F, GómezGarrido D, Pichierri P, Rinonapoli G, Meccariello L. Challenges in the management of floating knee injuries: Results of treatment and outcomes of 224 consecutive cases in 10 years. Injury. 2019;50(2):453461. doi: 10.1016/j.injury.2018.12.009. Epub 2018 Dec 11. Erratum in: Injury. $2019 \mathrm{Feb} ; 50(2): R 4$.

35. Rollo G, Bisaccia M, Irimia JC, Rinonapoli G, Pasquino A, Tomarchio A, Roca L, Pace V, Pichierri P, Giaracuni M, Meccariello L. The Advantages of Type III Scaphoid Nonunion Advanced Collapse (SNAC) Treatment With Partial Carpal Arthrodesis in the Dominant Hand: Results of 5 -year Followup. Med Arch. 2018 Oct;72(4):253-256. doi: 10.5455/ medarh.2018.72.253-256. Bisaccia M; Rinonapoli G; Meccariello L; Bisaccia O; Ceccarini P; Rollo G; IbaÃnez-Vicente C; Cervera-Irimia J; SanchezSanchez F; Ribes-Iborra A; Gomez-Garrido D; Caraffa A. Validity and Reliability of Mini-Invasive Surgery Assisted by Ultrasound in Achilles Tendon Rupture. Acta Inform Med. 2019; 27(1): 40-44. doi: 10.5455/aim.2019.27.40-44, Rollo G, Prkić A, Pichierri P, Eygendaal D, Michele Bisaccia M, Marco Filipponi M, Giaracuni M, Hitov P, Tanovskie K, Meccariello L. Plate-and-bone-strut fixation of distal third humeral shaft aseptic non-unions: A consecutive case series. DOI: https://doi.org/10.1016/j.jcot.2019.05.004

36. Rollo G, Meccariello L, Rotini R, Pichierri P, Bisaccia M, Fortina M. Efficacy of the "Salento technique", a modified two-incision approach in distal biceps brachii tendon repair. Surgical description and outcomes analysis. https://doi.org/10.1016/j. jcot.2019.02.006

37. Rollo G, Meccariello L, Bisaccia M, Pichierri P, Filipponi M, Giaracuni M, Di Giacomo LM, Zinghì G. Revision surgery for acetabular nonunion: role and challenges to preservation of hip joint. Clin Cases Miner Bone Metab. 2018 ;15(3):416-422.

38. Bisaccia M, Meccariello L, Rinonapoli G, IbáñezVicente C, Ribes-Iborra J, Gomez-Garrido D, Rollo G, Falzarano G, Shahid Khan M, Grubor P, Caraffa A. Reliability and value of external modular fixation (Hoffmann $\mathrm{II}^{\circledast}$ ) in the management of humeral shaft fracture. Clin Cases Miner Bone Metab. 2018 ;15(3):423-427.

39. Cuomo R, Nisi G, Brandi C, Giardino FR, Grimaldi L. Future Directions to Limit Surgical Site Infections. - J. Invest Surg. 2019 Mar 19:1-3. doi: 10.1080/o8941939.2019.1566420

40. Cuomo R, Nisi G, Grimaldi L, Brandi C, Sisti A, D'Aniello C. - Immunosuppression and Abdominal Wall Defects: Use of Autologous Dermis. - In Vivo. 2015 Nov-Dec;29(6):753-5.

41. Mancini S, Cuomo R, Poggialini M, D’Aniello C,
Botta G. - Autolytic debridement and management of bacterial load with an occlusive hydroactive deressing impregnated with polyhexamethylene biguanide. - Acta Biomed. 2018 Jan 16;88(4):409-413. doi: 10.23750/abm.v88i4.5802.

42. Rollo, G., Porcellini, G., Rotini, R., Bisaccia, M., Pichierri, P., Paladini, P., ... Meccariello, L. (2019). A new plate design to treat displaced 3-4 parts proximal humeral fractures in comparison to the most tested and used plate: Clinical and radiographic study. Medicinski Glasnik, 16(2), 284-291. https://doi. org/10.17392/1033-1943.

43. Bonura, E. M., Morales, D. J. O., Fenga, D., Rollo, G., Meccariello, L., Leonetti, D., ... Rosa, M. A. Conservative Treatment of Spondylodiscitis: Possible Therapeutic Solution in Case of Failure of Standard Therapy. Medical Archives 2019; 73(1), 39-43 https:// doi.org/10.5455/medarh.2019.7

44. Rollo, G., Prkic, A., Bisaccia, M., Eygendaal, D., Pichierri, P., Marsilio, A., ... Meccariello, L. Grafting and fixation after aseptic non-union of the humeral shaft: A case series. Journal of Clinical Orthopaedics and Trauma. 2019 https://doi.org/10.1016/j. jcot.2019.08.02045.

45. Rollo, G., Prkić, A., Pichierri, P., Eygendaal, D., Bisaccia, M., Filipponi, M., ... Meccariello, L. Plateand-bone-strut fixation of distal third humeral shaft aseptic non-unions: A consecutive case series. Journal of Clinical Orthopaedics and Trauma 2019;10, S127S132. https://doi.org/10.1016/j.jcot.2019.05.00446.

46. Rollo, G., Bisaccia, M., Rinonapoli, G., Caraffa,A., Pace, V., Irimia, J. C., ... Meccariello, L. Radiographic, Bone Densitometry and Clinic Outcomes Assessments in Femoral Shaft Fractures Fixed by Plating or Locking Retrograde Nail. Medical Archives (Sarajevo, Bosnia and Herzegovina), 2019; 73(3), 195-200. https://doi. org/10.5455/medarh.2019.73.195-20047.

47. Rollo, G., Bisaccia, M., Franzese, R., Pichierri, P., Filipponi, M., Giaracuni, M., ... Meccariello, L. (2019). The biomechanical potential of the bone graft in the proximal ulna non-union surgery. Clinical Cases in Mineral and Bone Metabolism. CIC Edizioni Internazionali s.r.l

48. Bisaccia, M., Rinonapoli, G., Meccariello, L., Ripani, U., Pace, V., Rollo, G., ... De Masi De Luca, A. (2019). Osteoporosis in male patients: Epidemiology, clinical aspects and DEXA Scan assessment. Clinical Cases in Mineral and Bone Metabolism. CIC Edizioni Internazionali s.r.l.

49. Rollo, G., Pichierri, P., Grubor, P., Marsilio, A., Bisaccia, M., Grubor, M., ... Meccariello, L. (2019). The challenge of nonunion and malunion in distal femur surgical revision. Medicinski Glasnik, 16(2). https://doi.org/10.17392/1016-1950.

50. Bisaccia, M., Rinonapoli, G., Meccariello, L., Bisaccia, O., Ceccarini, P., Rollo, G., ... Caraffa, A. (2019). Validity and reliability of mini-invasive surgery assisted by ultrasound in Achilles tendon rupture. Acta Informatica Medica, 27(1), 40-44. https://doi. org/10.5455/aim.2019.27.40-4451.

51. Cervera-Irimia J, González-Miranda Á, RiquelmeGarcía Ó, Burgos-Flores J, Barrios-Pitarque C, GarcíaBarreno P, García-Martín A, Hevia-Sierra E, Rollo G, Meccariello L, Caruso L, Bisaccia M. Scoliosis induced by costotransversectomy in minipigs model. Medicinski Glasnik 2019; 16(2), 157-163. https://doi. org/10.17392/1015-193.39-4344. 